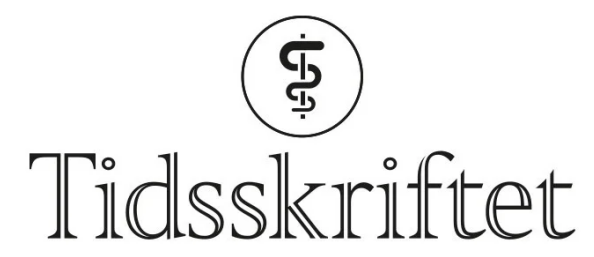

DEN NORSKE LEGEFORENING

\title{
E. Søegaard og Z. Kan svarer
}

KOMMENTAR

ERIK GANESH IYER SØEGAARD

erikganesh@hotmail.com

Erik Ganesh Iyer Søegaard er overlege og avdelingsleder.

\section{ZHANNA KAN}

Ingen av forfatterne har oppgitt noen interessekonflikter.

Takk for mange tilbakemeldinger gjennom Tidsskriftet og andre kanaler. Et hyppig forekommende spørsmål har vært test for multikollinearitet. Under fagfellevurdering og manuskriptbearbeiding ble også eksterne statistikere konsultert.

Cut-off for toleranse for multikollinearitet var satt til <0,1. Innvandrerandel, husstandstetthet og sosioøkonomisk status var i grenseland (o.1 - o.2). Imidlertid hadde ingen av dimensjonene varianseandeler over $0,9 \mathrm{i}$ kollinearitetsdiagnostikken. Vi endte med å beholde regresjonsanalysen med forbehold og nyansering av tolkningene som er tatt inn. Vi ønsker igjen å understreke at vår undersøkelse er preliminær og at den bør etterfølges med mer avanserte analyser, helst på individnivå.

På spørsmålet om kulturelle faktorer kan ha betydning for smitte, er det også andre kilder som peker i denne retningen. FHI skriver at "forskjellene vi observerer i bekreftet smitte forklares i liten grad av» forskjellige sosioøkonomiske faktorer (1). Boforhold er riktignok ikke med i disse analysene. Den samme rapporten viser også stor forskjell mellom hvert fødeland i Norge. Grupper med omtrent samme sosioøkonomisk situasjon varierer betydelig seg imellom i smitteforekomst.

Det kan være at norsk og nordisk kultur skiller seg spesielt ut. Sørover i Europa ser det ut til at forskjellene blir mindre og mindre, og i Italia har utenlandsfødte bare omtrent halvparten av smitteratene som etniske italienere (므). Atferd som er dypt iboende, ubevisst og automatisert fra barndommen som for eksempel naturlig nærhet til andre, gjestfrihet og kontakt, kollektivisme og inkludering, familiebånd og tro, kan være vanskelig å endre for en hel gruppe over tid. Slike elementer ved en kultur kan være risikofaktorer for smitte uavhengig av smitteverntiltak og vilje til å etterleve disse.

Vi ønsker ikke å stigmatisere eller utsette noen gruppe for usaklig forskjellsbehandling. Det er likevel mye som tyder på at tiltakene ikke fungerer godt nok for alle. Det kan hende at en annen vaksineprioritering kunne ført til mindre smitte totalt. Ved hovedsakelig lokalisert smitte har WHO tidligere anbefalt å prioritere disse områdene for vaksinering (3). 


\section{LITTERATUR}

1. Indseth T, Godøy A, Kjøllesdal M et al. Covid-19 etter fødeland fra mars 2020 til februar 2021. Oslo: Folkehelseinstituttet, 2021. https://www.fhi.no/publ/2021/covid-19-etter-fodeland-fra-mars-202O-tilfebruar-2021/ Lest 1.4.2021.

2. Scarpetta S, Dumont JC, Liebig T. What is the impact of the COVID-19 pandemic on immigrants and their children? Paris: OECD, 2020. https://www.oecd.org/coronavirus/policy-responses/what-is-theimpact-of-the-covid-19-pandemic-on-immigrants-and-their-children-e7cbb7de/ Lest 1.4.2021.

3. Roadmap for prioritizing population groups for vaccines against COVID-19. An Approach to Inform Planning and Subsequent Recommendations Based Upon Epidemiologic Setting and Vaccine Supply Scenarios. Genève: World Health Organization, 2020.

https://www.who.int/immunization/sage/meetings/2020/october/Sessiono3_Roadmap_Prioritization _Covid-19_vaccine.pdf Lest 4.4.2021.

Publisert:3. mai 2021. Tidsskr Nor Legeforen. DOI: 10.4045/tidsskr.21.0308

(C) Tidsskrift for Den norske legeforening 2023. Lastet ned fra tidsskriftet.no 26. april 2023. 